\title{
操船者を中心としたヒューマンエレメント
}

竹本孝弘 ${ }^{*} \cdot$ 住沢 裕介** 阪本 義治*** 古莊 雅生****

\section{A Study on Navigator-centered Human Element}

\author{
Takahiro TAKEMOTO, Yusuke SUMIZAWA \\ Yoshiharu SAKAMOTO and Masao FURUSHO
}

\begin{abstract}
We need to forge preventive measures that take into account human factors in order to prevent collision accidents. Not only are marine accidents caused by deeply concerning human factors, but many other accidents and disasters are as well. In this study, the authors studied factors that affect human elements on ship operations, and proposed the m-RSHEL Model which expands on the m-SHEL Model by expressing human factors based on the results. In addition, the authors focused attention on $\mathrm{R}$ (Human Resource) which is one of the important factors influencing human elements, and discovered the following results by investigating collision accidents that occurred in Tokyo Bay:
\end{abstract}

1) Personnel

The competency to properly use equipment, apparatus etc. for maneuvering, as well as observing SMS and legal restrictions for navigation

2) Manning

The manning of sufficient number of navigators who can fully identify and recognize other vessels to ensure safe navigation

3) Training

Training that determines and carries out safe distances from other vessels for the navigators of cargo or tanker vessels

Keywords: Marine Accident, Human Factor, Human Element, m-SHEL Model, Prevention of Collision Accident キーワード:海難、ヒューマンファクター、ヒューマンエレメント、m-SHEL モデル、衝突海難防止

1. はじめに

海難に関わらず、多くの事故、災害にはヒューマ ンファクターが深く関与しており、その防止にはヒ ューマンファクターに対する正しい理解とヒューマ ンファクターを考慮した防止対策が必要である。

ヒューマンファクターについては海難防止の観点 から多くの研究がなされているが、一方で IMO(国 際海事機関)を中心に海上事故対策等で利用される ヒューマンエレメントについては、一般に使用され ている明確な定義はなく、ヒューマンファクターの
同意語として使用される場合も多い。しかし、英国 の海事機関で、国際的に約 8000 人の会員を有寸る Nautical Institute(NI)はヒューマンファクターと ヒューマンエレメントを明確に区別し、事故防止に は海事産業に関わる人々がヒューマンエレメントに 関する共通の理解を持つことが重要であるとしてい る。

NI は船内作業におけるヒューマンエレメントを 構成する要素を検討し、2 章に示すヒューマンファ クターとヒューマンエレメントの関係を表現してい

\footnotetext{
* 正会員 東京海洋大学海洋工学部(

** 非会員 東京海洋大学大学院海洋科学技術研究科(干 135-8533 東京都江東区越中島 2-1-6)

*** 正会員 正会員 独立行政法人 航海訓練所( T243-0003 横浜市中区北仲通 5-57)

****正会員 神戸大学大学院海事科学研究科 $($ T 658-0022 神戸市東灘区深江南町 5-1-1)
} 
る。本研究では、この NI の検討結果に基づき、海 難防止を図る上で重要となるヒューマンエレメント の概念について、ヒューマンファクターを表現する 際に一般的に用いられる m-SHEL モデルを拡張し た、m-RSHEL モデルを提案した。さらにヒューマ ンエレメントを構成する重要な要素である R(Human Resource)に着目して船舶交通の輻輳し ている東京湾で発生した衝突海難を調査し、海難防 止について操船者を中心としたヒューマンエレメン トの観点から考察する。

\section{NI の提案するヒューマンエレメント}

一つのシステムを安全かつ效率的に運用寸るには、 システムの中心である人間(操作員)が操作しやすく、 かつ人間のエラー発生を押さえるために、仕事を人 間に適応させるさまざまな工夫が必要となる。黒田 は「ヒューマンファクターとは機械やシステムを安 全に、しかも有効に機能させるために必要とされる、 人間の能力や限界、特性などに関する知識の集合体」 と定義(1)して拈り、ヒューマンファクターは「仕事 を人間に適応させる」ための知識と捉えることがで きる。一方、事故防止という目的を達成するには人 間の特性を理解した上で「人間が仕事に適応する」 という考え方、すなわち仕事に人間を適忍させるた めにヒューマンリソースの充実を図ることも重要で ある。

NI はヒューマンエレメントとはヒューマンファ クターとヒューマンリソースを統合することであり、 船内作業においては「人間と船内のあらゆるシステ ムとの相互作業に影響するす心゙ての要素」と定義(2) している。船内作業におけるヒューマンリソースと は

・人員(Personnel)：船舶とそのシステムを運用・維 持するための適切な人員構成
・配乗(Manning)：通常及び非常時に船舶の安全運 航と保安及び海洋環境保護に必 要な乗組員数

・訓練(Training)：船舶とそのシステムに対する能 力と習熟度を維持・向上する訓練

により構成(3)されている。船内作業におけるヒュ ーマンファクター、ヒューマンリソース、ヒューマ ンエレメントの関係を Fig. 1 に示す。

\section{3. m-RSHEL モデル}

\section{1 SHEL モデル、m-SHEL モデル}

ヒューマンファクターの一般的な概念のモデルと して Edward が基本モデルを提案し、Hawkins が 改良した SHEL モデル(4)が利用される。このモデル は Software(S:ソフトウェア)、Hardware(H:ハー ドウェア)、Environment(E:環境)、 Liveware(L: 人間 中心の L は本人、それに接している L は関係 者)の境界にヒューマンファクターが存在すること を示している。（Fig. 2 参照）また河野はSHEL モ デルに全体の調和を図る Management(m:管理)を 追加した m-SHEL モデル(5)を提案している。(Fig. 3 参照）これらのモデルはヒューマンファクターの 概念を一般的に説明するものであり、海難分析とい った特定の分野の分析に利用するためには、モデル の各要素とその境界を具体化する必要がある。本研 究では衝突海難を分析対象とするため、操船者を中 心とし、モデルの各要素と境界を次のとおりとした。

(1) L : 人間

SHEL モデルにおける中心のLはシステムの使 用者としての人間を示し、本研究では操船者を示 す。また、中心のLに接続するもう一つの L はシ ステムの使用者に関わる他者を示し、当該船の船 橋にいる補助者、他船の操船者、VTS オペレータ 等が該当するが、本研究では操船者と直接的な接

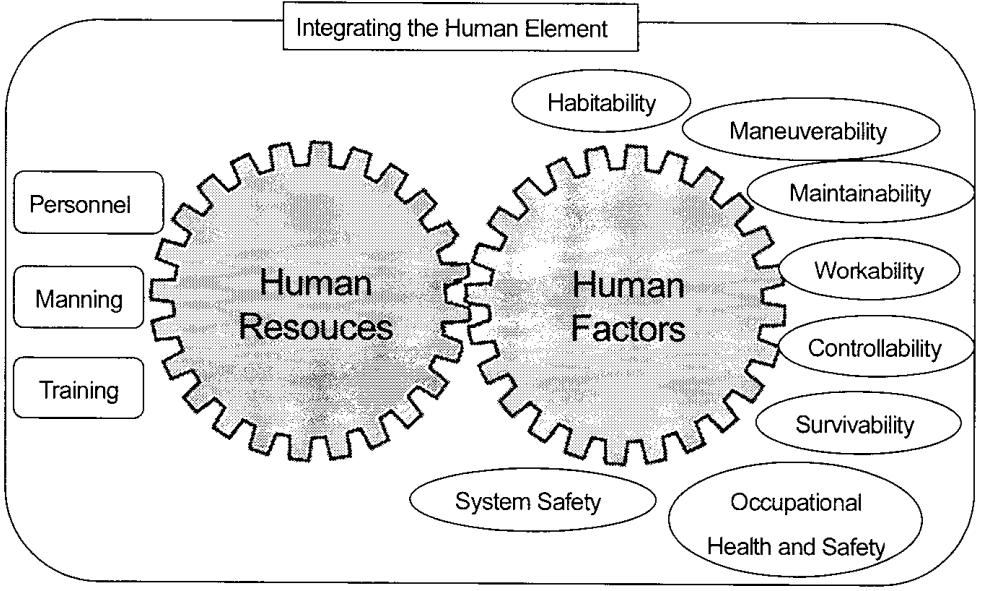

Fig. 1 The concept of human element

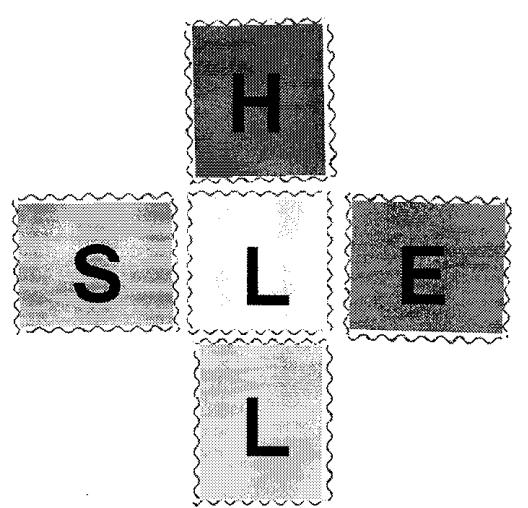

Fig. 2 SHEL model 
触のある補助者をもう一つのLと捉えた。

(2) L-L : 人間一人間

船舶の運航における L-L では、船内の人間関係 のほか、他船や航路管制との関係など、関連する 多くの要素が考えられる。本研究では、操船者の 観点から直接的な接触のある船橋内の人間関係を L-L として捉え、船外との人閒関係は、L-L とし ての関係よりも、環境や管理的な要素が強いと考 え、ここでは考慮しないものとする。

(3) L-H : 人間ーハードウェア

ハードウェアは人閒に適合させる最も重要な要 素であり、L-H の境界はヒューマンファクタ一を 取り扱う際に一般的に考慮されなければならない 領域である。一方でハードウェアがヒューマンフ アクターを十分に考慮した設計となっていなくて も、人間は L-H 問題にある程度適応する能力を有 しているが、このことが潜在的な仵険をもたらす 場合がある。

船舶航行における L-H では、操船者と航海支援 のための機器に関するものとする。

(4) L-S : 人閒ーソフトウェア

ハードウェア等のマニュアル、SMS(安全管理シ ステム)における規程、手順書、要領書類、チェッ クリスト類、法的な規則などのシステムの非物理 的な領域が L-S である。 L-H に比べて適合度合い の判断が曖昧で解決が難しい。

船舶航行における L-S では、操船に関わる設備 や機器等のマニュアル、航行に関する SMS や法的 規制として捉える。

(5) L-E : 人間一環境

人間と労働・作業環境に関わるものが L-Eである。 騒音や明るさ、温度などは $\mathrm{E}$ 要素として代表的なも のであるが、これらは耳栓や照明、作業着等の工夫 である程度解決できる場合がある。しかし、例えば 眠気や時差ぼけなど解決できない要素もある。

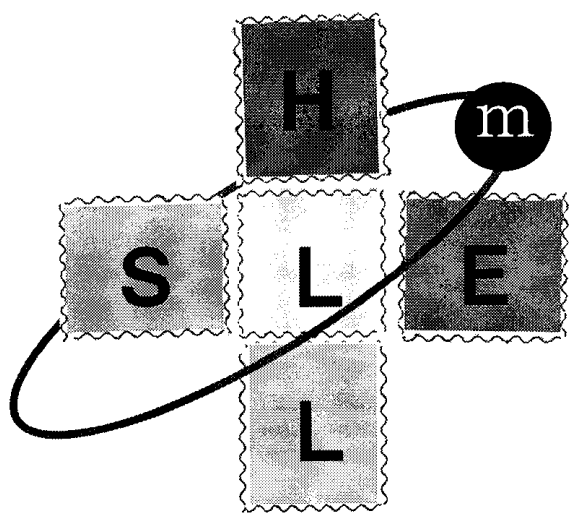

Fig. 3 m-SHEL model
船舶航行における L-E では、操船者の一般的な 労働・作業環境に加えて、視界不良、船舶交通輻 輳といった航行環境も L-Eとして取り扱う。

(6) $\mathrm{m}$ : 管理

これまで述べたようにヒューマンファクターは SHEL モデルの各要素の境界で発生している。分 析対象における L-L、L-H、L-S、L-Eの詳細を検 討することで、ヒューマンファクターを把握する ことができる。 $\mathrm{m}$-SHEL モデルで追加された $\mathrm{m}$ 要 素はSHELモデルではSまたは Eに含まれていた が、m はすべての要素の基盤であるとの考えから、 どこかの要素に含むのではなく、外側に出して包 括的に $\mathrm{m}$ の役割を強調したものが $\mathrm{m}$-SHEL モデ ルである。具体的には会社組織、管理体制、職場 の雰囲気作り、安全文化の醸成などを示す。

船舶航行における $\mathrm{m}$ は、船内で船長が行う管理、 会社や行政の管理等が考えられる。しかし船舶の 安全運航達成のための $\mathrm{m}$ 要素には、船舶の開発・ 設計製造を担う造船、船級協会、船舶運航管理会 社、荷主、陸上輸送機関といった船舶のライフサ イクルすべての海事産業を含める必要がある。

\section{2 m-RSHEL モデル}

有効な海難防止を実現するため、「仕事を人間に適 忘させる」というヒューマンファクターからのアプ ローチに加えて、「人間が仕事に適応する」というヒ ユーマンリソースの充実も必要となる。つまり NI の提唱するヒューマンエレメントの考え方に基づい た海難防止を確立することが重要となる。ヒューマ ンエレメントとはヒューマンファクターとヒューマ ンリソースの統合を意味することは既に述べた。そ こで、ヒューマンファクターを表現する m-SHEL モデルにヒューマンリソース $(\mathrm{R})$ 要素を加え、ヒュー マンエレメントの概念を表現する m-RSHEL モデ ルを提案する。(Fig. 4 参照)

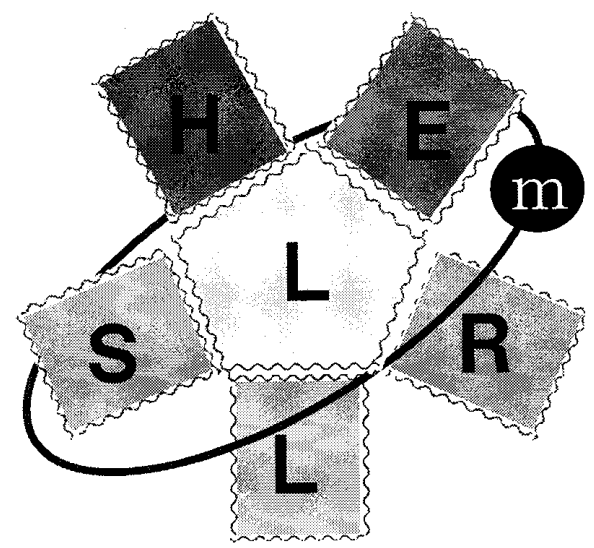

Fig. 4 m-RSHEL model 
前述した m-SHEL モデルの L を中心とする各要 素の境界は、中心の L のパフォーマンスを引き出す ために、周囲の要素を最適化することを意味してい る。一方、追加した R 要素は、中心の L がパフォー マンスを発揮するために確保しなければならないヒ ユーマンリソースを表現しており、船舶航行におけ る L-R：人間一ヒューマンリソースの境界は、船舶 を安全に航行させるためにL-S で定められた作業を 定められたとおりに実行する操船者、船橋当直で他 船の認識や動静の識別を十分に実行できる人数の操 船者の配乗、あらゆる航行環境下で船舶を安全に航 行させる能力及び習熟度を維持・向上するための操 船者の訓練である。 $\mathrm{R}$ 要素は $\mathrm{m}$-SHEL モデルの $\mathrm{m}$ 要素に含まれるものであるが、ヒューマンエレメン 卜の概念を表現するためには、 $\mathrm{R}$ 要素を分離するこ とで L-R 境界を明確に表現することができる。さら に当モデルを使用することで、中心の L を介する R 要素と他の要素との関係も表現できるメリットがあ る。

\section{4. 海難調査}

衝突海難防止のためのヒューマンリソースの役割、 すなわち m-RSHEL モデルにおける L-R の重要性 を確認するために、船舶交通が輻輳し、海難が発生 した場合には甚大な被害が予想される東京湾を対象 に衝突海難を調査した。海難審判裁決録から、衝突 海難の発生過程を表すツリーを作成し、海難防止を 図る上で必要な L-R を検討した。さらに調查結果か ら m-RSHEL モデルの有効性を確認した。

\section{1 調查対象}

海難審判裁決録(6)(7)に記載された平成 15 年から平 成 21 年までに東京湾内で発生した衝突海難(単独を 除く)50 件 100 隻を対象とした。

調査対象の操船者は、操船に係る L-R の情報を広 く収集するため、裁決に記載された受審人及び指定 海難関係人とした。そのため、衝突海難発生時に実 際には操船していなくても、衝突海難発生の原因と された関係者(報告や引継ぎ事項を明確に示さなか った場合等)も含め、97 人の操船者を調査した。ま た調查船舶は貨物船、油送船、旅客船、漁船、遊漁 船、モーターボート、引押船、その他(作業船、巡視 船、警備艇) に分類した。調査した操船者の資格、船 橋当直人数に対寸る操船者人数、船舶種類を Table 1 に示す。
Table 1 Investigated vessels and navigators

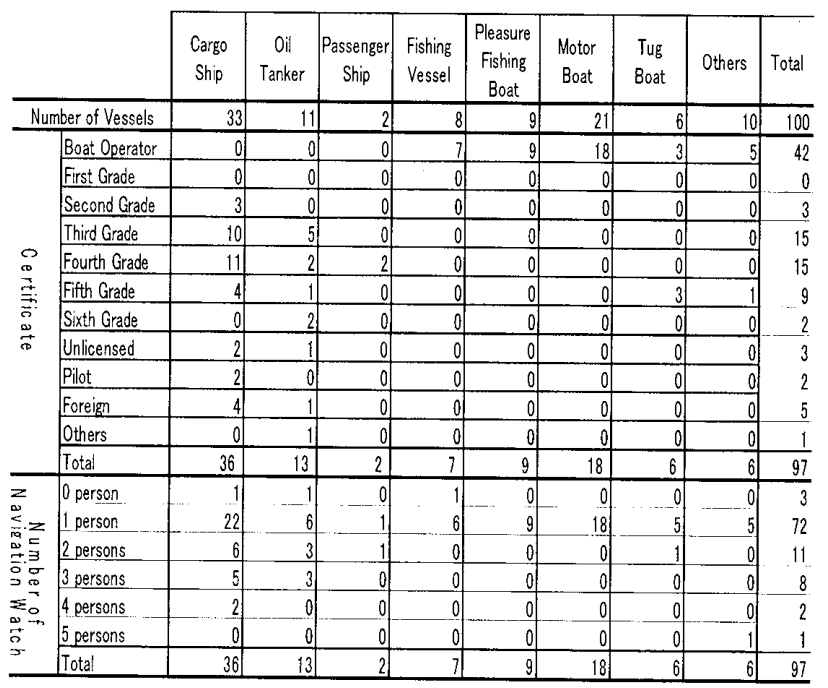

\section{2 調查方法}

調查のために作成したツリーを Fig. 5 に示す。ツ リーの各イベントには 97 人の操船者で発生した失 敗の件数を記入した。またヒューマンリソースを構 成する人員、配乗、訓練に該当するイベントにはそ れぞれ P、M、Tの記号を追記した。

調査ツリーでは、操船者に必要とされる能力を、 第一段階(発見、確認)、第二段階(衝突のおそれ発生 時からの判断)、第三段階(避航)に分け、操船者に各 段階でどのような失敗が発生しているのか、また、 服務に関寸る指揮・監督の不適切として、操船以外 で操船者に関わる失敗も調查した。

一人の操船者が複数の失敗を犯す場合もあり、失 敗の総数は操船者数 97 人之は一致しない。

（1）第一段階(発見・確認)での失敗

衝突のおそれの発生までに相手船を発見、確認 できなかったことを表すツリーである。そのため 衝突の直前に他船を発見し、衝突を避けるための 動作が間に合わない場合も第一段階での失敗とな る。衝突のおそれが発生する目安となる 2 船間の 距離は 2 海里とした。操船者が相手船の発見、確 認に失敗した場合の原因は「服務不完全」、「知覚 失敗」、「判断失敗」から構成され、それぞれにつ いて詳細の要素を決定し、失敗の発生件数、発生 パタンを調查した。

（2）第二段階(判断)での失敗

操船者が、相手船と衝突のおそれが発生した段 階から行った判断の失敗を表すツリーである。こ の第二段階は、「安全への配慮失敗」、「動静監視失 敗」及び「環境への配慮不十分」から構成され、 詳細の要素を決定、調査した。 


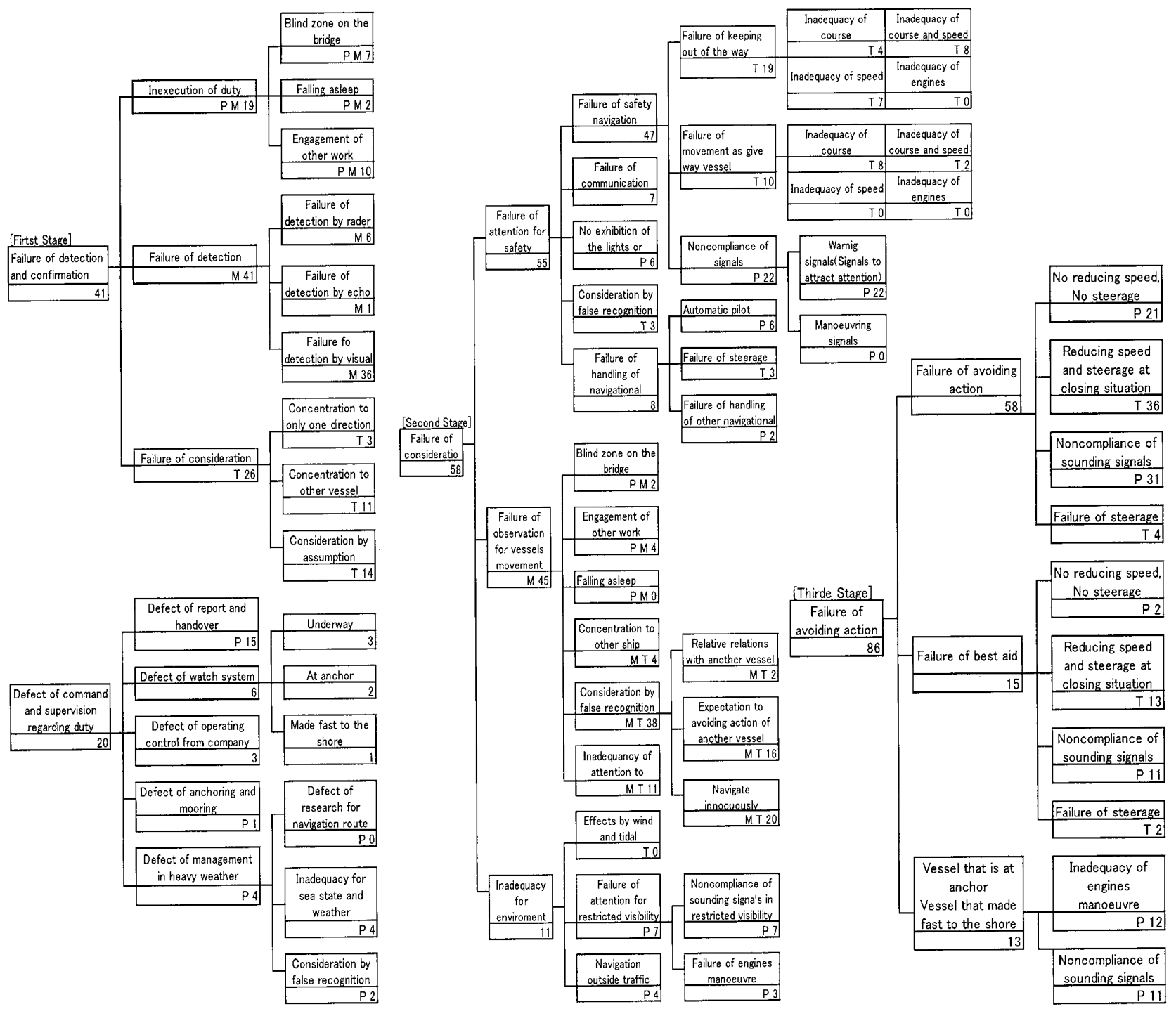

Fig. 5 Investigate tree of collision accidents

（3）第三段階(避航)での失敗

操船者が、衝突の危険が発生した段階から避航 判断の失敗を表すツリーである。このツリーでは 第二段階の「安全への配慮」で調査した「避航失 敗(保持船 - 避航船以外)」、「避航船としての動作失 敗」、「衝突回避動作失敗」に該当した操船者に対 して、衝突の乍険が発生してからの避航失敗につ いて調査した。このツリーは、「避航動作失敗」「協 力動作失敗」、「停泊船・錨泊船」から構成され、 詳細の要素を決定、調查した。

（4）服務に関する指揮・監督不適切

服務に関する指揮、監督の不適切により、船舶 を安全に運用させることができなかった場合を表 すツリーである。このツリーは、「報告・引継ぎの 不適切」、「当直体制不備」、「陸上からの船舶運航 管理の不適切」、「錨泊・係留の不適切」、「荒天措 置不適切」から構成され、詳細の要素を決定、調 查した。

\section{3 m-RSHEL モデルの有效性}

海難の 8 割、特に衝突海難ではその 9 割が操船者 や管理者のヒューマンファクターに起因するヒュー マンエラーにより発生していると言われる。今回実 施した調查ツリーを用いた衝突海難調査においても、 ツリーの最終イベントは服務に関する指揮・監督の 不適切ツリーにおける「航海中」、錨泊中」及び「航 海中」を除き、全てヒューマンエラーである。さら に服務に関する指揮・監督の不適切ツリーにおける 「陸上からの船舶運航管理の不適切」及び第二段階 ツリーの「他船との連絡失敗」以外は $\mathrm{R}$ 要素により 発生した操船者のヒューマンエラーである。このこ とからヒューマンエレメントにおける $\mathrm{R}$ 要素の重要 性、さらに $\mathrm{m}$ 要素から $\mathrm{R}$ 要素を分離して操船者を 中心としたヒューマンエレメントを表現する m-RSHEL モデルの有効性が確認できた。 


\section{5. ヒューマンエレメントと海難防止}

海難防止には操船者の行動特性を考慮した海難防 止には、ハードウェア、ソフトウェア、環境といっ た操船環境を操船者に適応させなければならない。 一方、ヒューマンエレメントの考え方に基づき、操 船者が操船環境に適応する対策も必要である。その ため、東京湾で発生した衝突海難の調査結果から、 海難防止のためのヒューマンエレメント、特にヒュ ーマンリソースを表すL-Rについて以下に述べる。

\section{1 人員}

安全航行における人員とは、船舶とそのシステム を運用・維持するための適切な人員構成」を意味す る。L-Rにおける「人員」の項目では、船舶を安全 に航行させるための作業を操船者が実行したから゙う かについて調查し、その際に必要となる適切な「能 力」の確保を検討した。他船の有無に関わらず、船 舶を安全に航行させるために行わなければならない 作業項目を Fig. 5 の調査ツリー各要素に P と追記し to

\section{（1）第一段階}

第一段階の「発見・確認失敗」で人員に関係す るのは見張り作業を実行しない「服務不完全」で あり、その原因は「船橋死角あり」、「居眠り」、「他 の作業に従事」に分類できる。操船者 97 人のうち 19 人が「服務不完全」に該当し、見張り作業を行 わなかった原因は、「他の作業従事(10人)」が最も 高く、次いで死角を補う見張りを行わなかった「船 橋死角あり 7 人)!であった。「他の作業従事」に ついてはモーターボート 5 人、漁船 2 人、遊漁船 2 人、油送船 1 人、油送船以外の操船者はす心゙て 小型船舶操縦士の資格を有していた。

（2）第二段階

第二段階の「判断失敗」では人員に関係する要 素として「安全への配慮失敗」、「動静監視失敗」、 「環境への配慮失敗」があり、多くの要素を含ん でいる。その中で最も発生件数が多いのは「信号 不履行 $(22$ 人)」で、その内容は「警告信号(注意喚 起信号 $(22$ 人)」で女った。「信号不履行」では小型 船舶操縦土資格のモーターボートが 8 名で最も多 い。次いで霧中信号や機関操作を行わない「視界 制限時の配慮失敗 $(7$ 人)」、不適切な海域での「自 動操舵(6人)」となっている。

(3) 第三段階

第三段階の「避航失敗」では人員に関する要素 として、「避航動作先敗」の要素である「減速・転 舵なし $(21$ 人)」及び「信号不履行(31人)」、協力
動作失敗」の要素である「減速・転舵なし $(2$ 人)」 及び「信号不履行 $(11$ 人)」、停泊船・錨泊船」の 要素である「機関始動不適切(12人)」及び「信号 不適切(11人)」となっている。「減速・転舵なし」 では小型船舶操縦士資格の遊漁船が 8 名で最も多 く、次いで三級から五級海技士の貨物船の 6 人之 なっている。また「機関始動不適切」では小型船 舶操縦士資格の漁船が 3 名、モーターボート9 名 であった。

（4）服務に関する指揮・監督

「服務に関する指揮・監督の不適切」では人員 に関するものとして「報告・引継ぎの不適切(15 人)」、「錨泊・係留の不適切(1人)」、「荒天措置不 適切」の原因である「気象海象への配慮不十分 $(4$ 人)」、「誤った認識による判断 $(2$ 人)」となってい る。「報告・引継ぎの不適切」では貨物船 8 人、油 送船 4 人であった。

以上のことから、L-Rにおける人員が原因で発生 する衝突海難を防止するには、特に次の能力を持っ た人負が必要である。

(1) 特に小型船舶操縦士資格を有する、漁船、遊漁船、 モーターボートの操船者に対して、他船との衝突 のおそれを発見する能力

(2) 衝突のおそれが発生した船舶に対して、適切に注 意喚起信号、警告信号を実施できる能力

（3）報告及び引継ぎを確実に実施できる能力

\section{2 配乗}

配乗とは「通常及び非常時に船舶の安全運航と保 安及び海洋環境保護に必要な乗組員数」を意味する。 L-Rに㧍ける「配乗」の項目では、安全航行のため に船橋当直で他船の認識や動静の識別を十分に実行 できる人数の操船者の配乗について調査した。配乗 に関係する項目を Fig. 5 の調査ツリ一各要素に M と追記した。

(1) 第一段階

第一段階の「発見・確認失敗」で配乗に関係す る主な原因は「探知失敗(41人)」であり、その要 素は「レーダ探知失敗 $(6$ 人)」、音探知失敗(1人)」、

「目視失敗 $(36$ 人)」となっている。「探知失敗」の 船橋当直人数を見ると、船橋当直 1 人の場合が最 も多く (37人)、船橋 2 人のときには発生していな い。残りは船橋 3 人以上で発生している。

(2) 第二段階

第二段階の「判断失敗」で配乗に関係する原因 は「動静監視失敗(45 人)」であり、その要素とし ては「誤った認識による判断(38人)」が最も多い。 
「䛊った認識による判断」とは他船の動静を識別 する際に、「他船との相詨関係」の判断を詰ったり

「他船の避航に期待」したり「無難に航行」でき ると判断する場合である。「誤った認識による判 断」の船橋当直人数を見ると船橋当直 1 人の場合 が最も多いが $(26$ 人)、船橋 2 人以上でも 11 人が該 当している。

以上のことから、L-R における配乗が原因で発生 する衝突海難を防止するには、特に次の点に注意が 必要である。

(1) 東京湾のような船舶交通が輻輳する海域では船 橋当直は 2 人以上で実施すべきである。

(2) 船橋当直を複数人数で実施する場合、他船を認識 し動静を識別する段階での失敗を防ぐ工夫が重要 である。

(3) 配乗では単に船橋当直人数を増やすのではなく、 情報の共有や役割分担といったブリッジリソース マネジメントの適切な実行を考慮しなければなら ない。

\section{3 訓練}

訓練とは「船舶とそのシステムに対する能力と習 熟度を維持・向上するための訓練」である。L-Rに おける「訓練」の項目では、船舶を安全に航行させ るための作業を操船者が実行したが、技術・能力不 足や習熟度不足により失敗した作業について調査し た。訓練に関係する項目を Fig. 5 の調査ツリー各要 素に Tと追記した。

(1) 第一段階

第一段階の「発見・確認失敗」で訓練に関係す るのは、他船を認識していたもののその動静を臆 断して「判断失敗(26 人)」となる場合で、その原 因は「一方向に集中 $(3$ 人)」、第三船に注意集中 $(11$ 人)」及び「思い込みによる判断(14人)」に分類で きる。「第三船に注意集中」は小型船舶操縦士の操 船者が 7 名と最も多く、遊漁船やモーターボート で発生している。「思い込みによる判断」も小型船 舶操縦士の操船者が 10 名と最も多く、遊漁船やモ ーターボートで発生している。

(2) 第二段階

第二段階の「判断失敗」では訓練に関係する原 因として「安全への配慮失敗」、「動静監視失敗」、

「環境への配慮失敗」があり、多くの要素を含ん でいる。その中で最も発生件数が多いのは配乗と 同じ「誤った認識による判断(38人)」で、その要 素の「無難に航行(20人)」が最も多く、次いで「他 船の避航に期待(16人)」となっている。「無難に航
行」での失敗は貨物船が 8 人、油送船が 5 人と多 く、漁船や遊漁船、モーターボートは各 1 人しか 失敗していない。また四級海技士免許所有者が 6 人、小型船舶操縦士が 5 人、三級海技士が 3 人と なっている。「他船の避航に期待」ではモーターボ 一トが 6 人、貨物船が 5 人、小型船舶操縦士が 9 人となっている。その他にも「避航失敗(19人)」、 「避航船としての動作失敗 $(10$ 人)」が大きな要素 である。

(3) 第三段階

第三段階の「避航失敗」では訓練に関する要素 として、「避航動作失敗」の要素である「間際での 減速・転舵 $(36$ 人)」及び「操舵失敗 $(4$ 人)」、「協力 動作失敗」の要素である「間際での減速・転舵(13 人)」及び「操舵失敗 $(2$ 人)」となっている。最も 多い「避航動作失敗」の要素である「間際での減 速・転舵」では貨物船 16 人、油送船 9 人、遊漁船 3 人、モーターボート 4 人、所有免許は小型船舶 操縦士 8 人、三級海技士 7 人、四級海技士 6 人、 五級海技士 8 人となっている。いずれも調査船舶 の船種割合、所有資格の資格別人数の割合と比較 すると、油送船が 11 隻で 9 人、五級海技士が 9 人 中 8 人とその発生割合が高い。

以上のことから、L-Rにおける訓練が原因で発生 する衝突海難を防止するには、特に次の点に注意す る必要である。

(1) 特に小型船舶操縦上資格を有する、遊漁船、モー ターボートの操船者は、見張りの注意を 1 隻に集 中したり、他船行動を臆断して見張りをおろそか にすることがないように、系統的・継続的な見張 りが実施できる訓練を行う。

(2) 貨物船や油送船の操船者は、衝突のおそれがある 船舶に対して、他船との安全な航過距離を決定し て、実行する訓練を行う。

(3) 輻輳海域を航行する操船者は、他船の避航に期待 せず、衝突のおそれが発生する前に行う先行避航 の訓練を行う。

(4) 避航船及び保持船の操船者として、避航行動を確 実に実行する訓練を行う。

\section{6. 結論}

操船者が犯すヒューマンエラーによる海難を防止 するには、ヒューマンファクター、ヒューマンエレ メントに関する理解と対策が必要である。本研究で は IMO 等の国際機関で広く使用されるようになっ てきたヒューマンエレメントを NI の考え方に基づ いて定義し、操船者を中心としたヒューマンエレメ 
ントを表現する m-RSHEL モデルを提案した。さら にL-Rに着目して、操船者が操船環境に適応するた めに必要なヒューマンリソースについて検討した。 その結果、衝突海難を防ぐために操船者に求められ る、特に重要なヒューマンリソースは次のとおりで ある。

(1) 人員

(1) 操船に関わる設備や機器等を適切に使用し、航 行に関する SMS や法的規制を遵守する能力

(2) 特に小型船舶操縦士の資格を有する操船者の 他船との衝突のおそれを発見する能力

(3) 衝突のおそれが発生した船舶に対して、適切に 注意㬇起信号、警告信号を実施できる能力

(4) 報告及び引継ぎを確実に実施できる能力

(2) 配乗

(1) 安全航行のために他船の認識や動静の識別を 十分に実行できる人数の操船者の配乗

(2) 船舶交通が輻輳する海域での 2 人以上での船 橋当直

(3) 船橋当直を複数人数で実施する場合、他船を認 識し動静を識別する段階での失敗を防ぐ工夫

(4) 情報の共有や役割分担といったブリッジリソ ースマネジメントの適切な実行

（3）訓練

(1) 特に小型船舶操縦士資格を有する操船者に対 する系統的・継続的な見張りの訓練

(2) 貨物船や油送船の操船者に対する、他船との安 全な航過距離を決定して、実行吉る訓練

(3) 輻輳海域を航行する操船者に対する先行避航 の訓練

(4) 避航船及び保持船の操船者として、避航行動を 確実に実行する訓練

$\mathrm{m}$-RSHEL モデルで示すとおり、 $\mathrm{R}$ 要素は中心の Lを介して他の要素と関連しており、今後はL-R-S、 $\mathrm{L}-\mathrm{R}-\mathrm{E}$ といった複合要因にも注目して海難防止策 を検討していく必要がある。

\section{参考文献}

（1）黒田勲：信じられないミスはなぜ起こるーヒュー マンファクターの分析-, pp.17-19, 平成 13 年, 中央労働災害防止協会

(2) Nautical Institute: Alert No.1, pp.4-5, 2003

(3) Nautical Institute: Alert No.11, pp.4-5, 2006

（4） $\mathrm{F} \cdot \mathrm{H} \cdot$ ホーキンス，黒田勲監修，石川好美監訳: ヒューマン・ファクター, pp.1-12, 1992, 成山堂
（5）河野龍太郎：原子力発電所におけるヒューマン ファクター, 高圧ガス 34[9]，pp.36-43，1997 年 9 月

（6）財団法人海難審判協会：裁決録検索システム(平 成 15 年 17 年), http://www2.maia.or.jp/ list.php, 平成 23 年 5 月

（7）海難審判所：HP 裁決の閲覧(平成 18 年 21 年), http://www.mlit.go.jp/jmat/saiketsu/saiketsu_k ako/04saiketsu.htm, 平成 23 年 5 月

（8）伊藤博子，三友信夫他：m-SHEL モデルを用い た船舶運航のヒューマンファクター分析，日本 航海学会論文集 第 110 号, pp.83-91, 平成 16 年 3 月

（9）福地信義：ヒューマンエラーに基づく海洋事 故, 海文堂, 平成 19 年 3 月

（10）住沢祐介:操船者を中心としたヒューマンエレ メントと海難防止, 東京海洋大学大学院海運口 ジスティクス専攻修士論文, 平成 23 年 9 月

\section{質疑応答}

嶋田陽一(神戸大学) :

事故の件数はいくつでしょうか。また、関係者に 加害者と被害者を含んでいるのでしょうか。もし被 害者を含める場合、解析結果に影響はないでしょう 功。

竹本孝弘 :

調査した衝突海難件数は 50 件、100 隻です。対 象操船者は 97 名で衝突隻数よりも少なくなってい ますが、これ停泊中・錨泊中に操船者不在の状態 で衝突された場合があるためです。海難審判では海 難原因調査に基づく関係者に対寸る懲戒の判断に力 点が置かれるため海難の関係者を加害者、被害者で 区別はしていません。今回の調査では関係者のどの ような行動が海難に結びついたのかといった観点で 調査を行っているので、解析結果には影響を与えて いないと考えます。

多田光男一(弓削商船高等専門学校)：

従来の SHEL モデルと比較して複雑となる m-RSHEL モデルを提案されているが、提案モデル が従来モデルに比べてどのようなメリットがあるの か具体的にコメントいただきたい。

竹本孝弘：

SHELモデルはヒューマンファクターを表現する モデルですが、今回提案した m-RSHEL モデルはヒ ユーマンエレメントを表現しています。ヒューマン エレメントはヒューマンファクターとヒューマンリ ソースを統合することとを意味しているので、 
SHEL モデルにリソース要素を追加することで、操 船者とヒューマンリソースの関係を明確に表現でき るメリットがあります。事故防止を考える場合は、 SHEL モデルの中心のLが最大の能力が発揮できる ように周囲の要素を最適化するだけでなく、中心の L もシステムの安全に最大限寄与する必要がありま す。そのために必要な要素がヒューマンリソースで、 m-RSHEL モデルで具体的に表現されるL-R 境界を 構成する要因を把握して、事故防止策を講じること が重要であると考えます。 